\title{
Application of Radioisotope $P^{32}$ for Treatment of Incurable Latent Syphilis
}

\author{
Preliminary Report \\ By
Osamu Miura, Toshio Nakajima and Ryusuke Mizumoto
（三浦修） (中島敏夫） (水本龍助)
From the Dermatological Department, Faculty of Medicine, Nihon University, Tokyo, Zapan. Director: Prof.
Osamu Miura

(Received for publication, September 29, 1953)

The therapy of syphilis has advanced by leaps and bounds since penicillin came into use for its treatment. However, the rate of recovery of latent syphilis cases has been low, variously reported as $48.4 \%,{ }^{11} 68.6 \%$ (in cases of incomplete previous treatment or $72.4 \%$ (in cases without previous treatment) ${ }^{2)}$ and $28.9 \%^{3}$ in early syphilis cases, and $47 \%$ (cases of unknown duration of disease), ${ }^{41} 55.43 \%$ (in cases of incomplete previous treatment) or $49.14 \%$ (in cases without previous treatment) ${ }^{21}$ and $18.2 \%{ }^{31}$ in late syphilis.

According to the reports of past researchers, ${ }^{516)}$ we are taught that the treponema pallidum responsible for latent syphilis are mainly distributed in the liver, the spleen and the lymph system in the patients. Also it has been reported ${ }^{78)}$ that $\mathrm{P}^{32}$ prefer entially is distributed in the same tissues. Accordingly, if $\mathrm{P}^{32}$ is administered to latent syphilis patients, may we not anticipate that the treponema pallidum colonies nestled in these tissues be deranged and thereby the action of the antiluetica be promoted? For the purpose of verifying such an anticipation, the following experiments were carried out.

\section{EXPERIMENTAL}

\section{Clinical Experiment}

1. Materials: As shown in Table I, six latent syphilis patients who refused to show negative sero-reaction after repeated antisyphilitic therapy were chosen as subjects, including two congenital syphilis, one late syphilis and three early syphilis cases. As reagent, $\mathrm{H}_{3} \mathrm{P}^{32} \mathrm{O}_{4}$ solution containing $5 \mathrm{mc}$. of $\mathrm{P}^{32}$ (15A-P in the catalogue of AEC) was diluted with about 20 cc. of distilled water to a concentration of $0.25 \mathrm{mc}$. per $1.0 \mathrm{cc}$., poured into ampoules and disinfected by boiling. 


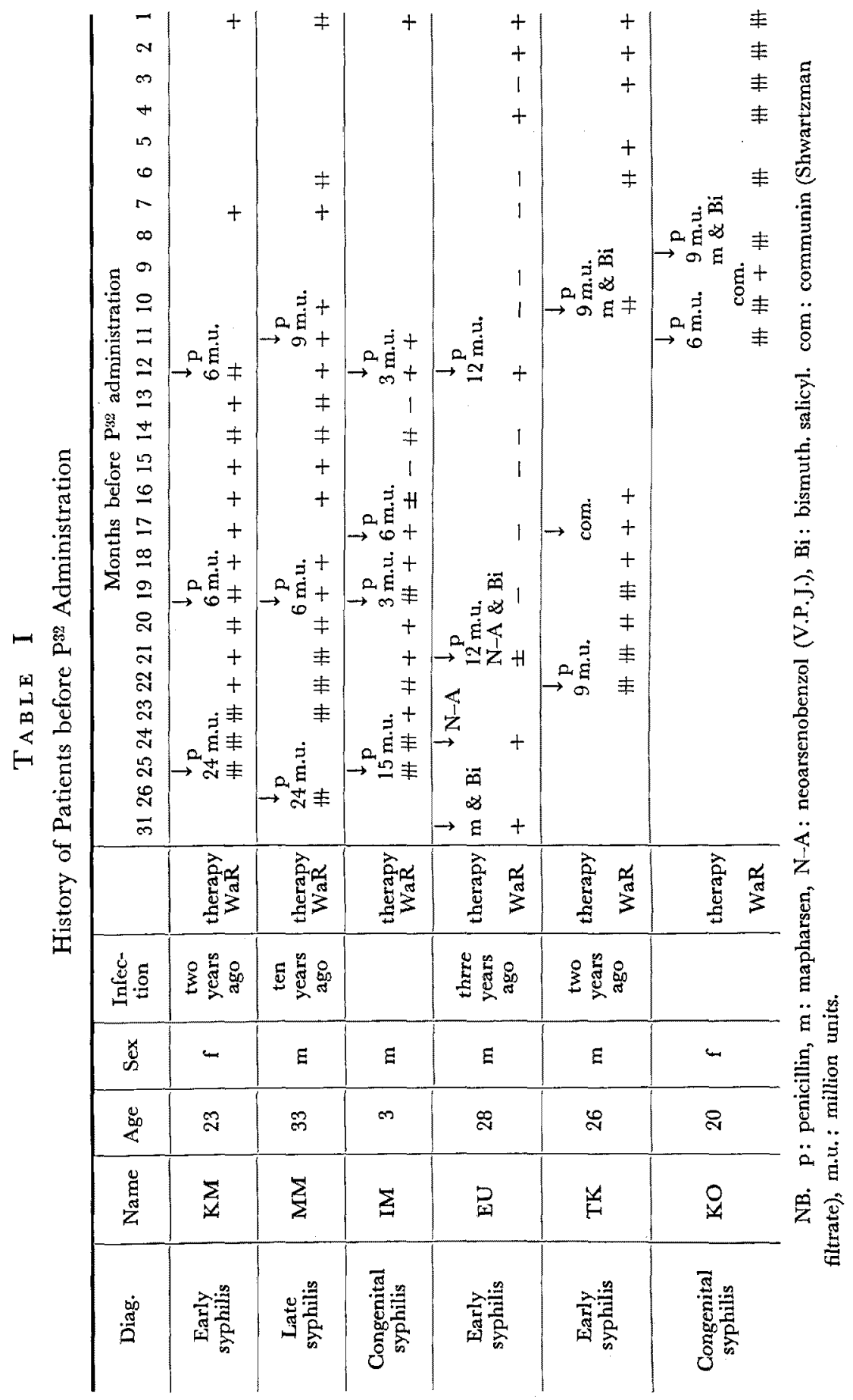


2. Method: $0.5 \mathrm{mc}$. of $\mathrm{P}^{32}$ each (half of the doses to an infant patient of congenital syphilis) was administered per case intravenously. Excepting three cawes, one case each of congenital, late and early syphilis who were used as controls, the remaining three cases were subjected to penicillin therapy beginning about 10 days after the $\mathrm{P}^{32}$ injection. Observation was kept up for nearly one month after the injection, not only their sero-reaction, but also urobilinogen and urobilin in their urine, their hematologic findings (including serum protein level, specific gravity of serum, sedimentation rate of erythrocytes etc.) and the $\mathrm{pH}$ values of their saliva were tested by routine method, and the radio-activity of their peripheral blood extracted from their earlobes, of their venous blood, urine and feces was measured by means of a Geiger-Müller radiation counter. Their serum-reaction was followed up for several months thereafter, tested once every month.

3. Results: i) Cases injected with $\mathrm{P}^{32}$ alone. By WaR tests, all the cases, including one congenital syphilis case, male, three years old, one late syphilis case, male, 33 years old and one early syphilis case, married female, 23 years old, showed unmistakable fluctuation of sero-reaction. In particular, the late syphilis case complained of pain at the distal end of the right humerous and the proximal end of the right tibia and a feeling of distension of the epigastrium, in the very night following the injection. Upon examination on the next day, the liver was found swollen above the right mammillary line by two fingers' breadth and feeling pain upon pressure. That night, he began to feel stricture of the pharynx and hoarseness, as well as weakening of sight. The pain at the liver and the long bones disappeared in five days, followed by the relief from the closeness of the pharynx and the hoarseness, but the enlargement of the liver took about half a month to abate (Table II).

The hematologic findings and the results of the other routine clinical examinations showed more or less fluctuations, but no case showed any marked deviation above physiologically normal ranges. The radioactivity of the earlobe blood of the late syphilis patient became inappreciable after 18 days, but in all other samples of blood, urine and feces, it diminished daily, but remained detectable even about one month after the injection (Table III).

ii) Cases treated with penicillin after $\mathrm{P}^{32}$ injection. One of the tested two early syphilis cases became negatively reactive in $\mathrm{WaR}$ test upon injection, but the other cases, consisting of one early and one congenital syphilis cases, showed no change in serum WaR. The three cases were injected each with 9,000,000 units of procaine penicillin $G$ in total, in 15 doses of 600,000 units per injection, administered every second days starting from around the 11 th day after the $\mathrm{P}^{32}$ injection. The case who 
turned WaR negative immediately upon $\mathrm{P}^{32}$ injection remained negative in the 5th month after the injection, but the two other cases showed no change in their positive reaction down to the 4th month following the treatment (Table II). The observations on hematologic findings and radioactivity showed similar results as those by the cases injected with $P^{32}$ alone described in i) above.

\section{Experiments with Animals}

1. Materials: 11 rabbits of about three $\mathrm{kg}$. each in body weight inoculated with syphilis germs in their testicles with positive WaR, were used 100 days to 12 months after the inoculation. Four of them were administered procaine penicillin $G$, three others were injected with $P^{32}$ and the remaining four were subjected to penicillin treatment thereafter, and the effect of such treatments on the serum reaction was observed in the three groups. The Nichols' strain and Kojimachi strain of rabbit syphilis germs donated by Dr. Shiro Someya of the Institute of Public Health, Tokyo, were used for inoculation, at which operation the kind suggestion of Mr. Rin Awano of the same Institute proved of great value. We hereby express our gratitude due to both of them.

The same grade of $\mathrm{P}^{32}$ used with human subjects mentioned above was used in the following experiments.

2. Method: The control group was injected with approximately 70,000 units per kg. of body weight of procaine penicillin $\mathrm{G}$ intragluteally. $\mathrm{P}^{32}$ was administered in a dose of $0.04 \mathrm{mc}$. per $\mathrm{kg}$. of body weight per test by injection into the auricular veins. When both the reagents were applied, penicillin was administered as described above $48 \mathrm{hrs}$. after the injection of $\mathrm{P}^{32}$. In every case, sero-reaction was kept under observation for 65 days thereafter.

3. Results: i) Effect of penicillin injection on the sero-reaction of syphilized rabbits (Table IV). With the rabbit No. 8, treated seven months after the inoculation with Nichols' strain, the reaction turned negative once at the outset but relapsed positive in a short time, to gain permanent negativity 60 days afterwards. Another rabbits No. 10 treated five months after the inoculation turned negative 60 days after the penicillin injection in Murata reaction alone, with no change in WaR throughout. No. 9, treated five months after the inoculation with Kojimachi strain, showed fluctuation in both Murata reaction and $\mathrm{WaR}$, but died on the 11 th day. No. 11, treated three months after the inoculation of Nichols? strain also showed such fluctuations and died on the 13th day of experiment.

ii) Effect of $\mathrm{P}^{32}$ on ditto (Table V). The rabbit No. 5, injected with $\mathrm{P}^{32} 12$ months after the inoculation with Kojimachi strain, showed 
TABLE

Radioactivity in some Materials

(Count per min. on Geiger-

\begin{tabular}{|c|c|c|c|c|c|c|c|c|c|}
\hline Diag. & Name & Age & Sex & \multicolumn{2}{|l|}{ Materials } & Day & 2 & 4 & 5 \\
\hline Early syphilis & $\mathrm{KM}$ & 23 & $\mathbf{f}$ & $\begin{array}{l}\text { peripheral blood } \\
\text { venous blood } \\
\text { urine } \\
\text { feces }\end{array}$ & $\begin{array}{ll}0.01 & \mathrm{cc} \\
0.1 & \mathrm{cc} \\
0.1 & \mathrm{cc} \\
0.1 & \mathrm{~g}\end{array}$ & $\begin{array}{l}31.35 \\
112.8 \\
655.7 \\
578.4\end{array}$ & $\begin{array}{r}17.4 \\
48.4 \\
302.7 \\
223.4\end{array}$ & $\begin{array}{r}10.2 \\
39.4 \\
216.4 \\
113.7\end{array}$ & $\begin{array}{r}9.2 \\
39.4 \\
145.8 \\
108.8\end{array}$ \\
\hline Late syphilis & MM & 33 & $\mathrm{~m}$ & $\begin{array}{l}\text { peripheral blood } \\
\text { venous blood } \\
\text { urine } \\
\text { feces }\end{array}$ & $\begin{array}{ll}0.01 & \mathrm{cc} \\
0.1 & \mathrm{cc} \\
0.1 & \mathrm{cc} \\
0.1 & \mathrm{~g}\end{array}$ & $\begin{array}{r}17.4 \\
295.8 \\
555.3 \\
281.4\end{array}$ & $\begin{array}{l}10.85 \\
59.7 \\
496.7 \\
224.4\end{array}$ & $\begin{array}{r}9.5 \\
45.4 \\
263.7 \\
211.7\end{array}$ & $\begin{array}{l}8.85 \\
39.4 \\
227.4 \\
169.8\end{array}$ \\
\hline $\begin{array}{l}\text { Congenital } \\
\text { syphilis }\end{array}$ & IM & 3 & m & $\begin{array}{l}\text { peripheral blood } \\
\text { venous blood } \\
\text { urine } \\
\text { feces }\end{array}$ & $\begin{array}{ll}0.01 & \mathrm{cc} \\
0.1 & \mathrm{cc} \\
0.1 & \mathrm{cc} \\
0.1 & \mathrm{~g}\end{array}$ & $\begin{array}{r}33.7 \\
150.4 \\
758.7 \\
246.7\end{array}$ & $\begin{array}{r}20.9 \\
91.8 \\
377.9 \\
240.4\end{array}$ & $\begin{array}{r}16.7 \\
71.7 \\
295.4 \\
201.8\end{array}$ & $\begin{array}{r}14.2 \\
57.4 \\
232.4 \\
167.4\end{array}$ \\
\hline Early syphilis & $\mathrm{EU}$ & 28 & $\mathrm{~m}$ & $\begin{array}{l}\text { peripheral blood } \\
\text { venous blood } \\
\text { urine } \\
\text { feces }\end{array}$ & $\begin{array}{ll}0.01 \mathrm{cc} \\
0.1 \mathrm{cc} \\
0.1 \mathrm{cc} \\
0.1 \mathrm{~g}\end{array}$ & $\begin{array}{r}48.9 \\
177.7 \\
9918.8 \\
240.4\end{array}$ & $\begin{array}{r}8.0 \\
120.8 \\
635.4 \\
120.8\end{array}$ & $\begin{array}{r}3.7 \\
51.7 \\
251.7 \\
92.2\end{array}$ & $\begin{array}{c}3.35 \\
38 \\
145.4 \\
73\end{array}$ \\
\hline Early syphilis & TK & 26 & $\mathrm{~m}$ & $\begin{array}{l}\text { peripheral blood } \\
\text { veneous blood } \\
\text { urine } \\
\text { feces }\end{array}$ & $\begin{array}{ll}0.01 & \mathrm{cc} \\
0.1 & \mathrm{cc} \\
0.1 & \mathrm{cc} \\
0.1 & \mathrm{~g}\end{array}$ & $\begin{array}{r}16.7 \\
64.4 \\
447.4 \\
147.4\end{array}$ & & & \\
\hline $\begin{array}{c}\text { Congenital } \\
\text { syphilis }\end{array}$ & $\mathrm{KO}$ & 20 & $\mathrm{f}$ & $\begin{array}{l}\text { peripheral blood } \\
\text { venous blood } \\
\text { urine } \\
\text { feces }\end{array}$ & $\begin{array}{ll}0.01 & \mathrm{cc} \\
0.1 & \mathrm{cc} \\
0.1 & \mathrm{cc} \\
0.1 & \mathrm{~g}\end{array}$ & $\begin{array}{r}55.2 \\
180.4 \\
1540.4\end{array}$ & $\begin{array}{l}30.7 \\
161 \\
248.7\end{array}$ & $\begin{array}{r}13.7 \\
104.7 \\
201.8 \\
595.4\end{array}$ & \\
\hline
\end{tabular}

negative sero-reaction from the 4th day but on the 11 th day, the reaction began to rise stronger than ever. No. 6 and 7, treated some eight months after the inoculation with Nichols' strain, showed intensified positive reaction from the $3 \mathrm{rd}$ and 5 th days respectively. The latter two died on the 9 th and 12 th days.

iii) Fluctuation of sero-reaction upon $\mathrm{P}^{32}$ administration followed by penicillin therapy (Table VI). The rabbit No. 1, treated with $\mathrm{P}^{32}$ eight months after the inoculation with Kojimachi strain, immediately showed a rise in the sero-reaction, but upon injection of penicillin $48 \mathrm{hrs}$. afterwards, the reaction became negative, intensified on the 7 th day following the $\mathrm{P}^{32}$ injection or the 4th day after penicillin administration, and dropped again to negativity 60 days afterwards for good. No. 2 and 3, treated three months after the inoculation with Kojimachi and Nichols' strains respectively, showed no change in sero-reaction upon injection either of $\mathrm{P}^{32}$ or of penicillin. The former died in 18 days, while the latter ives and is under observation, now 65 days after the first treatment. No. 
III

after $\mathrm{P}^{32}$ Administration

Müller's radiation counter)

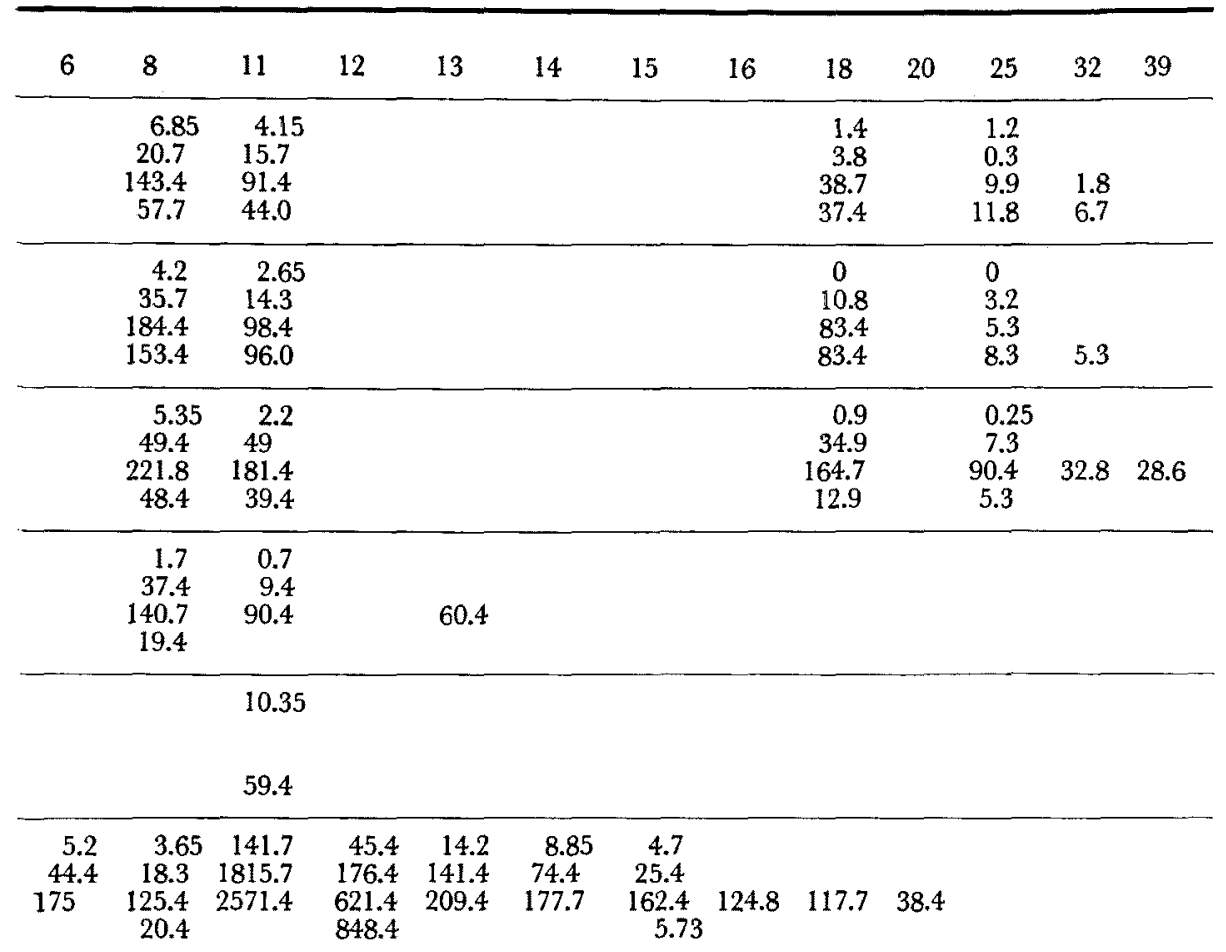

4, treated three months after the inoculation with Nichols' strain showed fluctuations in sero-reaction following injections of both $\mathrm{P}^{32}$ and penicillin, but died in 15 days.

\section{Summary AND Discussion}

Noticing that the tissues where treponema pallidum is observed in existence in latent syphilis cases and where $\mathrm{P}^{32}$ is found precipitated with preference are about the same, we undertook the above experiments for promoting the efficiency of antiluetica by taking advantage of derangement occasioned by $\mathrm{P}^{32}$ in the colonies of syphilis germs entrenched in those tissues in incurable latent cases. In the experiments we assumed that the resistance in sero-reaction indicated persistence of syphilitic condition. The results obtained may be summarized as follows. Upon administration of $\mathrm{P}^{32}$ to latent syphilis patients in various stadia showing resistance against negation of sero-reaction by means of any available antiluetic therapy, it 


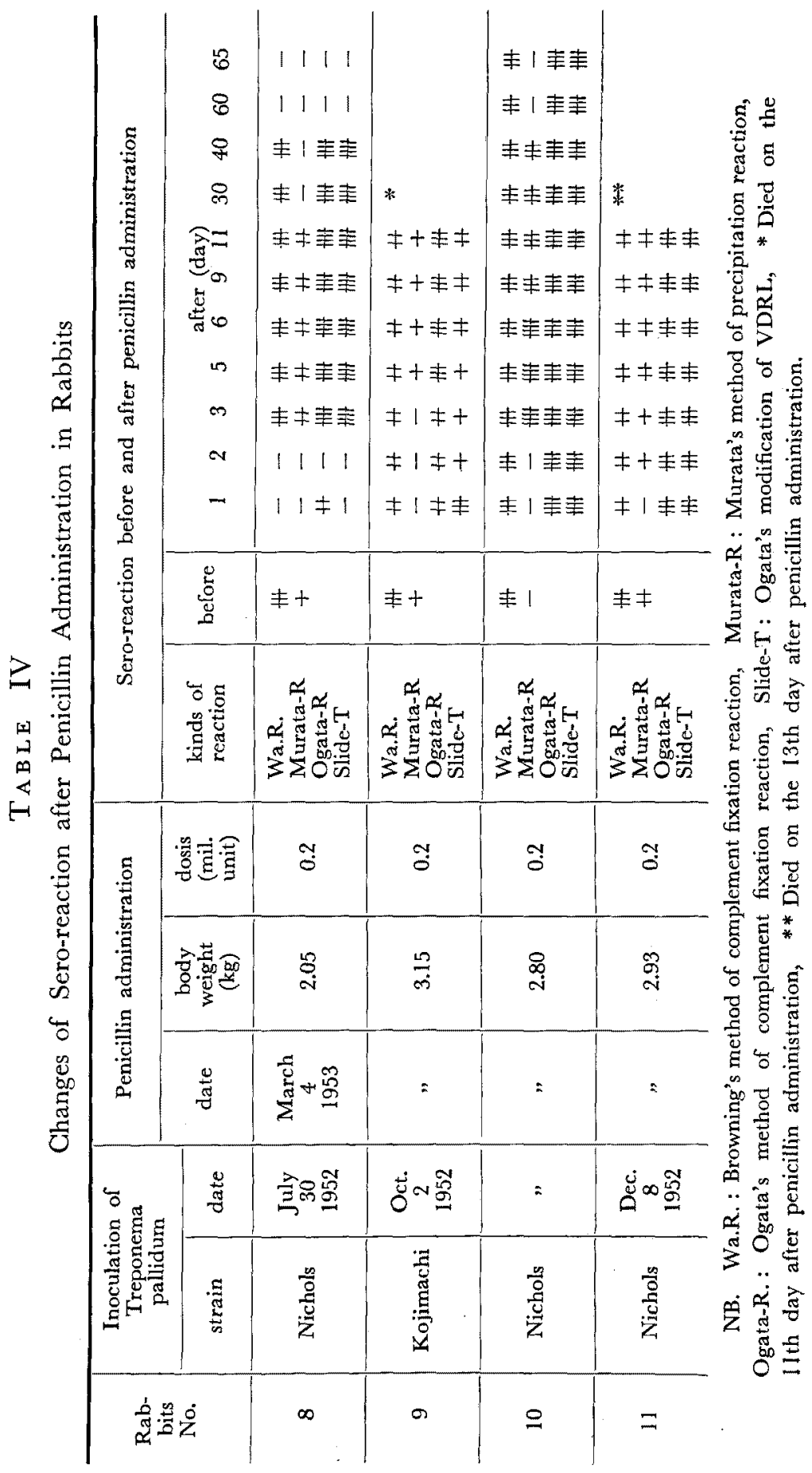




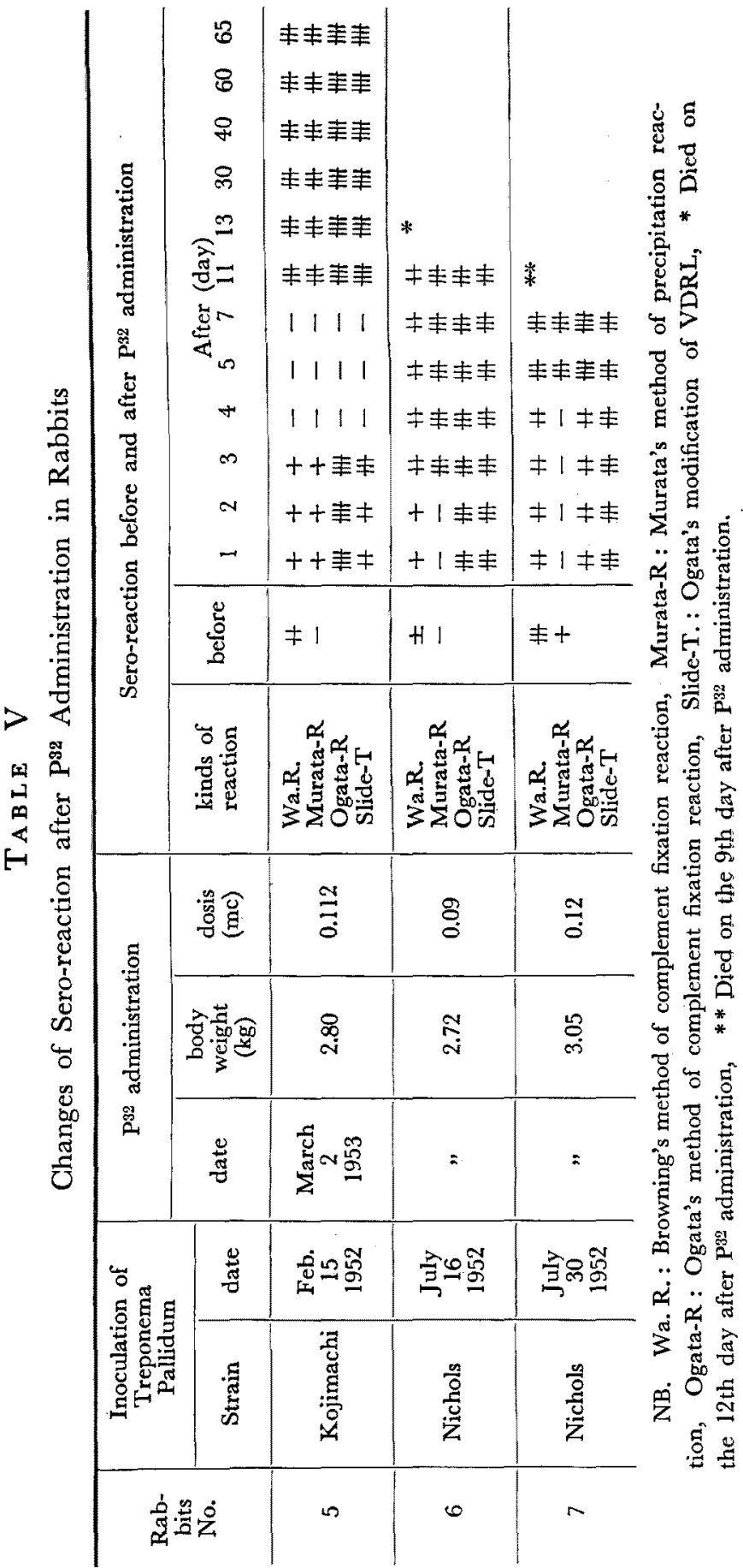




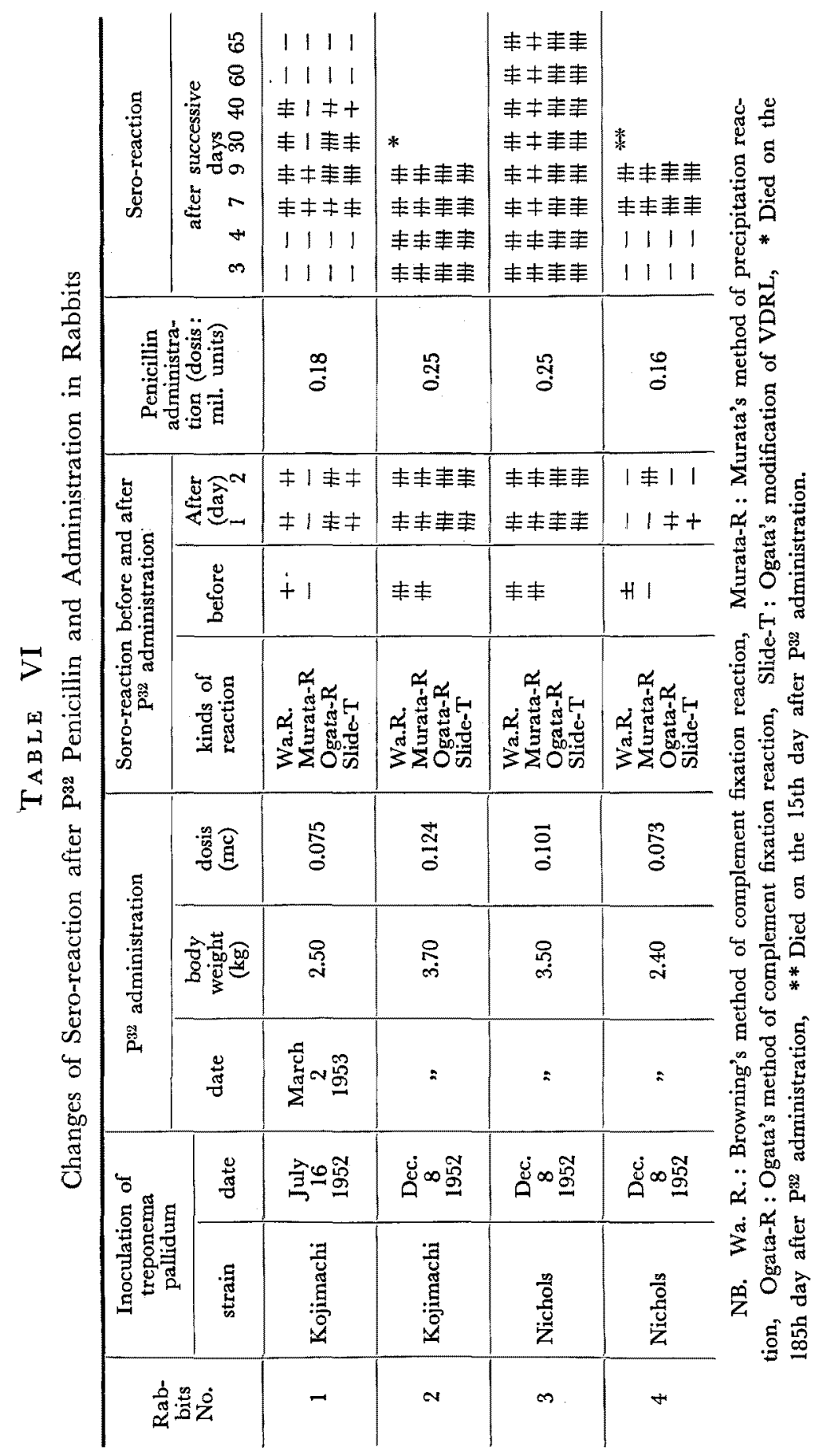


was found that a dose of $0.5 \mathrm{mc}$. of $\mathrm{P}^{32}$ could not effect any changes in WaR of a female congenital syphilis case, 20 years of age, and of an early syphilis case of 26 years old man, but the other four, early, late and congenital syphilis cases thus treated showed frank fluctuations of WaR. Two early and one congenital syphilis cases, including the two former with no change in sero-reaction, were given additional treatments with nine million units of penicillin each starting from around 10 days after the $\mathrm{P}^{32}$ injection. One of them turned negative in his $\mathrm{WaR}$ and the subsequent penicillin treatment succeeded in keeping the negative in his WaR five months afterwards, but the other two cases failed to respond, either to $\mathrm{P}^{32}$ or to the penicillin therapy.

However, we must note that one late syphilis case began to complain of pain at the ends of the long bones of the extremities, enlargement of the liver with tenderness, noarseness and weakening of visual faculty upon injection of $\mathrm{P}^{32}$. This fact, together with the fluctuations in $\mathrm{WaR}$ observed by four of the six tested cases, seems to throw a ray of hope in the realization of the intended derangement of treponema pallidum.

All the three cases of syphilized rabbits injected with $\mathrm{P}^{32}$ solution showed decided fluctuations in their sero-reaction, two of them dying in 9 and 12 days respectively. Also all the four cases with $\mathrm{P}^{32}$ injection followed up with penicillin administration showed similar fluctuation and two of them died in 15 and 18 days respectively. Our observation of 65 days, however, revealed permanent negative WaR only in one case out of 11 tested.

In any case, one thing seems to be undisputable, namely, that, in both the latent syphilis cases and the syphilized rabbits, the injection of $\mathrm{P}^{32}$ occasioned fluctuations of sero-reaction, and we may be justified in assuming that this effect was due to the derangement of treponema pallidum by the biotropism of the radioactive $P^{32}$. We regret to state that we were restricted in our experimental activities on human and animal subjects owing to the strict limitation in time available for the procurement of $\mathrm{P}^{32}$, so that we are herewith forced to give out a preliminary report on our past experiments, though we are far from being satisfied with our rather cursory works.

We hereby express our heartfelt gratitude due to Prof. Nobutane Mori and all the staff members of the Physiological Laboratory of this University for their valuable assistance and suggestions, which enabled us to accomplish the parts in our experiments connected with handling of radioactive matters. It must be also mentioned with thanks that the cost of these experiemnts were defrayed from the Fund for Scientific Research allocated by the Education Ministry. 


\section{References}

1) Report of the Blue Star Study, quoted by Beerman et al., Arch. Int. Med., 1953, 91, 636.

2) Takenouchi et al., Rinsho-Hifu-Hinyoka (Jap.), 1952, 6, 613.

3) Okano \& Nakajima, Seibyo (Jap.), in press.

4) Willcox, Lancet, 1947, II, 8.

5) Tani et al., Juzenkaizasshi (Jap.), 1928, 33, 675.

6) Uhlenhuth \& Grossmann, Klin. Wschr., 1927, 292.

7) Tuttle et al., quoted by Fassbendar, Dtsch. med. Wschr., 1952, 77, 368.

8) Low-Beer et al., Amer. J. Roentgenol., 1952, 67, 28. 